\title{
LEARNING COMMUNITY DALAM PERKULIAHAN UNTUK MEMBANGUN KEMAMPUAN BERPIKIR KREATIF MAHASISWA
}

\section{Wayan Sukarjita}

\author{
Universitas Nusa Cendana \\ corresponding Author: wayansukarjita@yahoo.co.id
}

DOI: $10.24929 /$ lensa.v10i1.93

Received: ' 17 Maret 2020

Revised: 20 Maret 2020

Accepted: 19 Mei 2020

\begin{abstract}
ABSTRAK
Penelitian ini bertujuan untuk menganalisis kemampuan berpikir kreatif mahasiswa Program Studi Pendidikan fisika FKIP Undana dalam perkuliahan yang berbasis Learning Community. Data diambil dengan menggunakan kuisioner kemampuan berpikir kreatif dengan lima indikator kemampuan berpikir kreatif, yaitu: berpikir lancar, berpikir luwes, berpikir orisinil, berpikir elaboratif dan berpikir evaluatif. Sampel penelitian berjumlah 26 mahasiswa yang merupakan peserta kuliah matakuliah Strategi Pembelajaran Fisika pada semester Ganjil 2019/2020. Data kemampuan berpikir kreatif mahasiswa dianalisis secara deskriptif kualitatif dan kuantitatif. Hasil penelitian menunjukkan bahwa (1) Learning Community (LC) merupakan salah satu bentuk pembelajaran yang berpusat pada mahasiswa (Student Centered Learning) yang menitik beratkan pada konsep belajar dalam kelompok, saling bekerjasama, sharing dan menciptakan suasana belajar untuk saling belajar dalam wadah komunitas belajar sehingga tercipta proses pembelajaran yang lebih bermakna dan berkualitas; (2) Pembelajaran dalam bentuk Learning Community pada perkuliahan Stategi Pembelajaran Fisika efektif untuk membentuk kemampuan mahasiswa dalam berpikir kreatif yang mencakup lima aspek yaitu kemampuan dalam berpikir lancar, luwes, orisinil, elaborasi dan evaluatif dengan ketercapaian rerata sebesar 84,14 persen; (3) Pembelajaran dalam bentuk Learning Community pada perkuliahan Stategi Pembelajaran Fisika efektif dalam meningkatkan kemampuan berpikir kreatif mahasiswa perserta kuliah Stategi Pembelajaran Fisika secara umum sebesar 17,24 persen.
\end{abstract}

Kata Kunci: Learning Community, Berpikir Kreatif.

\begin{abstract}
The purpose of this study is to analyze the ability to think creatively for students of the Physics Education Program Study of FKIP Undana in lectures based on Community Learning. The data was taken with a questionnaire of creative thinking ability with five indicators, namely: smooth thinking, flexible thinking, original thinking, elaborative thinking and evaluative thinking. The research sample consisted of 26 students who were participants in Physics Learning Strategy course subjects in Odd semester 2019/2020. Data were analyzed descriptively qualitatively and quantitatively. The results showed that (1) Learning Community (LC) is a form of studentcentered learning that focuses on the concept of learning in groups, working together, sharing and creating a learning atmosphere to be more meaningful and a higher quality learning process (2) Learning in the form of Learning Community in Physics Learning Strategic lectures is effective for shaping student skills in creative thinking that includes five aspects, namely skills in smooth thinking, flexible, original, elaboration and evaluative with an average achievement of 84.14 percent; (3) Learning in the form of Learning Community in Physics Learning Strategic lectures is effective in improving the creative thinking skills of students participating in Physics Learning Strategies in general by 17.24 percent.
\end{abstract}

Keywords: Learning Community, Creative Thinking.

\section{PENDAHULUAN}

Perguruan Tinggi merupakan salah satu jenjang pendidikan yang menjadi sentral pengembangan Sumber Daya Manusia (SDM). Ouput sebuah perguruan adalah 
ketersediaan SDM yang siap kerja sesuai kompetensi yang dimiliki saat menempuh jenjang pendidikan. Pemerintah melalui Kemenrintek Dikti telah berupaya meningkatkan kualitas output SDM Perguruan Tinggi agar lulusannya memiliki kemampuan dan kemampuan yang memadai sesuai kebutuhan dunia kerja. Salah satu bentuk upaya tersebut adalah adanya perubahan dan penyesuaian kurikulum yang berlaku di tingkat Perguruan Tinggi. Perubahan kurikulum ini bertujuan untuk menyesuaikan kebutuhan dunia kerja yang semakin kian berubah seiring perkembangan teknologi dan informasi yang begitu pesat.

Lahirnya pengembangan kurikulum di Perguruan Tinggi yang berbasis Kerangka Kualifikasi Nasional Indonesia (KKNI) sejak Tahun 2015, membawa dampak besar dalam bentuk dan pola pembelajaran di Perguruan Tinggi. Jika Kurikulum sebelumnya yang berbasis kompetensi (Kurikulum Berbasis Kompetensi atau KBK) lebih menekankan pada aspek kognitif, maka pada kurikulum berbasis KKNI konsep pengembangannya tidak hanya pada aspek kognitif akan tetapi lebih menekankan pada aspek sikap dan keterampilan, yang meliputi keterampilan umum dan keterampian khusus (Permenristek Dikti, 2015).

Pengembangan kompetensi pada aspek sikap dan keterampilan dalam kurikulum perguruan tinggi memberikan makna bahwa bahwa pengembangan soft skill demikian sangat berarti dalam pencapaian pembelajaran. Soft skill mencakup dua aspek keterampilan yaitu keterampilan dalam menjalin relasi dengan orang lain (interpersonal skills) dan keterampilan dalam mengatur dan mengelola dirinya sendiri secara mandiri (intrapersonal skills). Elfindri, dkk (2012) juga mengatakan bahwa soft skill merupakan keterampilan dan kecakapan hidup yang dimiliki seseorang, baik untuk diri sendiri, berkelompok ataupun dalam bermasyarakat. Soft skill ini antara lain dapat berupa keterampilan berkomunikasi, keterampilan berbahasa, keterampilan berkelompok keterampilan emosional, keterampilan spiritual, serta memiliki etika, moral dan sopan santun. Oleh karena itu, maka proses pembelajaran dalam perkuliahan sebagaimana tuntutan kurikulum berbasis KKNI harus dapat memberikan kesempatan kepada mahasiswa untuk mengembangkan soft skill-nya dalam setiap akitvitas proses pembelajaran.

Pengembangan kurikulum berbasis KKNI di Perguruan Tinggi membawa dampak adanya perubahan paradigma tentang proses pembelajaran (perkuliahan) yang terjadi di Perguruan Tinggi. Perubahan paradigma pembelajaran tersebut adalah perubahan paradigma pembelajaran (perkuliahan) dari pembelajaran yang berpusat pada dosen (Teacher Centered Learning) menjadi pembelajaran yang berpusat pada mahasiswa (Student Centered Learning atau SCL). 
Demikian halnya di Universitas Nusa Cendana, khususnya di Program Studi Pendidikan Fisika penerapan kurikulum mengacu pada KKNI telah dilaksanakan sejak Tahun 2017. Sebagai program studi yang menghasilkan calon guru di tingkat sekolah menengah, implementasi pembelajaran yang berorientasi pada kurikulum berbasis KKNI diharapkan membawa dampak positif terhadap peningkatan kompetensi lulusan baik dari aspek kognitif maupun aspek sikap dan keterampilan. Penguasaan soft skill oleh mahasiswa sebagai calon guru dipandang sangat penting mengingat lulusan nantinya harus mampu tampil sebagai guru yang professional dan mampu berinteraksi secara baik dengan siswa. Sebagaimana disebutkan oleh Slamento (2010) bahwa hasil belajar siswa antara lain dapat pula diperngaruhi oleh hubungan dan interaksi antara guru dengan siswa maupun antara siswa dengan siswa. Oleh Karena itu, mahasiswa sebagai calon guru perlu dibekali secara dini tentang pengelolaan interaksi dalam kelas pembelajaran.

Salah satu bentuk pembelajaran yang dapat dijadikan sebagai pembelajaran yang mengarahkan proses pembelajaran ke bentuk student centered learning antara lain adalah pembentukan komunitas belajar (Learning Community atau disingkat LC) dalam kelas. Learning community yang dalam bahasa Indonesia dapat diterjemahkan menjadi komunitas belajar. Komunitas belajar adalah sekelompok orang yang melakukan pertukaran nilai-nilai umum atau keyakinan dan secara aktif bersepakat untuk belajar bersama satu dengan yang lain. (Istamar Syamsuri dan Ibrohim, 2008). Learning Community berkaitan erat dengan konsep belajar melalui layanan komunitas dalam sebuah komunitas belajar (Louise Stoll, 2006). Layanan komunitas bermakna terciptanya suasana yang memberi kesempatan kepada peserta didik untuk saling ber interaksi dan saling belajar satu sama lainnya. Suasana seperti inilah yang perlu diciptakan oleh pendidik (dosen) selama proses pembelajaran. Lebih jauh Lillie G, Jessie (2007) menegaskan bahwa LC dapat menciptakan suasana pembelajaran yang responsif antara pendidik dengan peserta didik terhadap fakta-fakta pembelajaran yang terjadi di kelas.

Learning Community adalah bentuk pembelajaran yang lebih menekankan pada peran teman sebaya dalam sebuah komunitas belajar yang terbentuk dalam small group learning, dimana dalam proses pembelajarannya terjadi interaksi positif multiarah yang saling belajar antara mahasiswa dalam kelompoknya. Sebagaimana ditegaskan oleh Kurniawan (2018) bahwa pembelajaran teman sebaya dapat menumbuhkan karakter sosial peserta didik dalam aspek kerjasama. Dalam LC, setiap mahasiswa memiliki hak yang sama dalam belajar, tidak ada yang saling menggurui satu sama lainnya akan tetapi bersama untuk saling belajar. Setiap mahasiswa akan saling membantu dalam mencari dan menemukan pengetahuan secara bersama dalam bentuk collaborative learning. 
Pembelajaran LC terfokus pada bentuk pembelajaran dalam kelompok-kelompok kecil yang heterogen yang dilandasi atas keinginan bersama untuk saling belajar, tidak ada kompetisi atau persaingan kelompok tetapi setiap individu dalam kelompok berbagi pengalaman belajar sehingga tercipta suasana untuk saling belajar. Penelitian tentang pembelajaran dalam bentuk $L C$ berbasis inkuiri terbimbing pernah dilakukan oleh Yuli Munazah (2015) yang diterapkan pada mata pelajaran IPA Fisika untuk siswa SMP. Hasil penelitiannya menyimpulkan bahwa bentuk pembelajaran $L C$ berbasis inkuiri terbimbing mampu meningkatkan hasil belajar siswa baik aspek kognitif, afektif maupun psikomotorik. Sementara itu. Pembelajaran LC juga pernah diterapkan pada mata pelajaran IPS SMP oleh Hotmaidah Sinaga (2017) dalam bentuk Penelitian Tindakan Kelas (PTK). Hasil penelitiannya menyimpulkan bahwa penerapan pembelajaran LC dapat meningkatkan prestasi belajar siswa dengan ketuntasan belajar mencapai 90 persen.

Menurut Sudirtha (2017), terdapat tiga elemen penting dalam pembelajaran yang berbasis LC yaitu: fokus pada pembelajaran (menjamin bahwa siswa atau mahasiswa belajar), budaya kolaborasi, dan berorientasi pada hasil. Hal ini mengindikasikan bahwa bentuk pembelajaran LC memberikan perluang dan kesempatan kepada mahasiswa untuk belajar secara mandiri, berinteraksi secara multiarah dalam bentuk kolaboratif sehingga tercipta suasana pembelajaran yang terpusat pada mahasiswa (Student Centered Learning). Sementara itu, Mustadi (2018) mengatakan bahwa LC merupakan salah satu cara untuk memberikan kemerdekaan bagi peserta didik agar dapat saling belajar dengan teman sebaya secara kolaboratif.

Pada Program Studi Pendidikan Fisika, telah diterapkan pembelajaran berbasis LC pada beberapa matakuliah. Pada Semester Genap 2018/2019 diterapkan pada mata kuliah Fisika Lingkungan dan Dasar-dasar Pendidikan MIPA, sedangkan pada Semester Ganjil 2019/2020 diimplementasikan pada matakuliah Strategi Pembelajaran Fisika.

Salah satu aspek yang ditekankan dalam pembelajaran berbasis LC ini adalah adanya keterlibatan semua anggota kelompok mahasiswa dalam mencari dan menemukan secara bersama kosep yang akan gali. Selain aspek kognitif, apektif dan soft skill yang menjadi target utama dalam pembelajaran LC ini, pembelajaran LC juga untuk mengembangkan kemampuan mahasiswa dalam meramu dan mengkolaborasikan semua kompetensi yang dimiliki sehingga menjadi suatu pembelajaran yang dapat diterima oleh semua anggota kelompok. Setiap anggota kelompok diberikan kesempatan yang sama untuk mengemukakan pendapat dan pikirannya sehingga terelaborasi dalam sebuah pikiran yang cerdas dan kreatif. Oleh karena itu, salah satu aspek kognitif yang dapat dibangkitkan melalui pembelaran berbasis $L C$ adalah kemampuan mahasiswa dalam berpikir kreatif. Menurut Saefudin (2012), berpikir kreatif dapat diartikan sebagai bentuk kegiatan mental yang dipergunakan oleh seseorang dalam membangun ide-ide 
atau gagasan yang baru. Sementara itu, Mahmudi (2010) lebih menekankan makna berpikir kreatif pada kemampuan seseorang dalam menghasilkan solusi yang baru dan bervariasi.

Berpikir kreatif dapat didefinisikan kedalam empat dimensi: berfokus pada pribadi, proses, dorongan dan produk. Kreatif berfokus pada pribadi muncul dari keunikan keseluruhan kepribadian dalam interaksi dengan lingkungannya. Kreatif yang berfokus pada dimensi proses mencerminkan kelancaran, keluwesan, dan orisinal dalam berpikir, serta kemampuan untuk mengelaborasi (mengembangkan, memperkaya, memperinci) suatu gagasan. Kreatif dalam dimensi dorongan internal diri sendiri berupa keinginan dan hasrat untuk mencipta atau bersibuk diri secara kreatif, maupun eksternal dari lingkungan sosial dan psikologis. Kreatif dalam dimensi produk berfokus pada apa yang dihasilkan oleh individu baik sesuatu yang baru/original atau sebuah elaborasi/penggabungan yang inovatif (Festiyed, 2016). Terkait pada dimensi proses, Purwaningrum (2016) mengatakan bahwa proses pembelajaran yang inovatif dengan membentuk kelompok-kelompok kecil (group) dapat membangkitkan kemampuan berpikir kreatif peserta didik.

Berpikir kreatif merupakan kemampuan seseorang dalam mendayagunakan seluruh potensi yang dimilikinya yang setiap saat muncul dalam berbagai keadaan. Berpikir kreatif adalah cara seseorang dalam berpikir yang dipenuhi dengan ide atau gagasan-gagasan dalam mengembangkan daya imajinasinya (Jona, 2010). Konsep kolaborasi dalam LC memberikan kesempatan kepada peserta kuliah untuk saling sharing ide-ide inovatif yang muncul berdasarkan daya imajinasi masing-masing mahasiswa. Ide-ide inovatif inilah merupakan cikal munculnya kreativitas mahasisa yang dapat dinyatakan dalam bentuk gagasan-gagasan baru maupun dalam bentu karya atau produk. Sebagaimana dinyatakan oleh Surya (2013) bahwa pikiran kreatif merupakan proses atau tindakan yang menjadi sarana untuk merangsang dan memunculkan berbagai potensi maupun bakat yang tersembunyi dari dalam diri seseorang menjadi sebuah talenta, gagasan maupun sebuah hasil karya yang bermutu. Bahkan, Soeyono (2014) memandang berpikir kreatif sebagai sebuah kemampuan berpikir divergen dalam menemukan solusi yang baru dengan menekankan pada aspek kelancaran, keluwesan, keaslian dan elaborasi.

Lebih jauh ditegaskan oleh Sani (2014), bahwa berpikir kreatif akan dapat menghasilan pemikiran yang bermutu, sehingga kemampuan berpikir kreatif adalah kemampuan untuk mengembangkan ide-ide yang berkualitas, tidak biasa dan merupakan salah satu bentuk upaya mengembangkan diri terhadap ide-ide baru yang bermutu baik. Sementara itu, Susanto (2013) menegaskan bahwa berpikir kreatif pada dasarmya adalah sebuah proses yang melibatkan berbagai unsur seperti unsur orisinalitas, kelancaran, fleksibelitas, dan elaborasi. Hal ini menunjukkan bahwa 
kemampuan berpikir kreatif akan dapat mengembangkan daya pikir peserta didik agar memiliki wawasan dengan unsur unsur daya pikir yang lebih luas. Oleh karena itu, perlu tercipta suasana pembelajaran yang mendukung terbentuknya kemampuan berpikir kreatif peserta didik. Firdausi (2018) pernah melakukan penelitian untuk menganalisis kemampuan berpikir kreatif siswa ditinjau dari gaya belajar pada pembelajaran Model Eliciting Activities (MEA). Hasil penelitiannya menyimpulkan bahwa gaya belajar pada pembelajaran MEA berpengaruh positif untuk meningkatkan kemampuan berpikir kreatif siswa. Pemberian masalah yang bervariasi dalam proses pembelajaran, dapat pula meningkatkan kemampuan berpikir kreatif siswa, sebagaimana hasil penelitian yang dilakukan oleh Putri (2017). Penelitian tentang kemampuan berpikir kreatif di kalangan mahasiswa pernah dilakukan oleh Suripah (2017) yang hasil penelitiannya menyimpulkan bahwa mahasiswa matematika dengan kemampuan akademik yang tinggi memiliki cara berpikir yang lebih kreatif.

Berdasarkan beberapa pendapat sebagaimana telah diuraikan di atas, dapat dikatakan bahwa kemampuan berpikir kreatif perlu dikembangkan dalam proses pembelajaran. Berpikir kreatif merupakan sebuah proses interaktif yang dapat memunculkan ide-ide baru serta yang tidak biasa sehingga menghasilkan pemikiran baru dengan cakupan wawasan yang lebih luas, kritis dan inovatif.

Sehubungan dengan itu, maka telah dilaksanakan sebuah penelitian dengan mengkaji implementasi perkuliahan berbasis LC dalam upaya mengembangkan kemampuan berpikir kreatif mahasiswa.

Adapun masalah yang dikaji dalam penelitian ini adalah bagaimana kemampuan berpikir kreatif mahasiswa Program Studi Pendidikan fisika FKIP Undana dalam perkuliahan yang berbasis Learning Community?. Tujuan Penelitian ini adalah untuk menganalisis kemampuan berpikir kreatif mahasiswa Program Studi Pendidikan fisika FKIP Undana dalam perkuliahan yang berbasis Learning Community.

\section{METODE PENELITIAN}

Penelitian ini dilaksanakan selama satu semester pada semester Ganjil Tahun Akademik 2019/2020 di Program Studi Pendidikan Fisika, FKIP Undana. Populasinya adalah mahasiswa Semester III Program Studi Pendidikan Fisika dengan sampel penelitian mahasiswa peserta kuliah untuk matakuliah Strategi Pembelajaran Fisika yang berjumlah 26 orang. Cakupan meteri dalam penelitian ini meliputi: Konsep dasar strategi pembelajaran efektif, Teori-teori belajar dalam pembelajaran, Pendekatan pembelajaran, Strategi Pembelajaran, Metode dan Teknik Pembelajaran, Model pembelajaran, Pemilihan materi dan media pembelajaran, Pengelolaan kelas dan Penelitian berbasis strategi pembelajaran. 
Metode penelitian yang digunakan adalah Pre-Experimental dengan model desain One-Group Pretest-Posttest Design (Hastjarjo, 2019). Untuk mengukur kemampuan berpikir kreatif dipergunakan instrument yang disusun dalam skala likert. Menurut Sugiyono (2013), skala likert dapat dipergunakan untuk mengukur variabel sikap, pendapat, fenomena, ataupun persepsi seseorang atau beberapa orang. Dalam penelitian ini, instrumen kemampuan berpikir kreatif terdiri atas 5 aspek yaitu: (1) berpikir lancar, (2) berpikir luwes, (3) berpikir orisinil (4) berpikir elaboratif dan (5) berpikir evaluative. Dalam penelitian ini, untuk mengembangkan kemampuan berpikir kreatif mahasiswa peserta kuliah Strategi Pembelajaran Fisika, perkuliahan dilaksanakan dalam bentuk Small Group Discussion (SGD) dan Case Study (Study Kasus). Seminggu sebelum perkuliahan, seluruh komunitas belajar dalam bentuk kelompok-kelompok kecil telah diberi tugas berupa topik atau materi kuliah yang akan dibahas pada pertemuan berikutnya. Setiap komunitas wajib mempersiapkan materi atau topik yang akan dibahas dengan mencarinya (search, proses inkuiri) secara on line.

Mahasiswa dalam pembelajaran LC ini dibentuk dalam enam kelompok kecil dengan empat kelompok jumlah anggotanya empat orang, dan dua kelompok anggotanya lima orang. Anggota kelompok ditentukan secara heterogen terutama dari aspek keterampilan berinteraksi dan berkomunikasi. Keanggotaan kelompok ini tidak tetap, namun akan berubah setiap pergantian topik materi atau rerata setiap dua kali pertemuan tatap muka. Tujuannya agar konsep pembelajaran LC yakni saling belajar dalam keragaman komunitas tetap terjaga, serta memberikan kesempatan kepada setiap anggota untuk berinteraksi dan saling belajar dengan seluruh anggota kelompok lainnya. Data kemampuan berpikir kreatif mahasiswa pasca perlakuan berupa perkuliahan yang berbasis $L C$ dianalisis secara deskriptif baik secara kualitatif maupun secara kuantitatif. Indikator aspek kemampuan berpikir kreatif dalam penelitian ini sebagaimana Tabel 1 merupakan kombinasi dan modifikasi dari indikator kemampuan berpikir kreatif yang dikemukakan oleh Liliawati (2011) dan Anisa, dkk (2018).

Tabel 1. Indikator Kemampuan Berpikir Kreatif

\begin{tabular}{|c|l|l|}
\hline No & \multicolumn{1}{|c|}{ Aspek } & \multicolumn{1}{c|}{ Indikator } \\
\hline 1 & $\begin{array}{l}\text { Berpikir } \\
\text { lancar }\end{array}$ & $\begin{array}{l}\text { 1. Mengajukan banyak bentuk dan variasi pertanyaan } \\
\text { 2. Menjawab pertanyaan dengan lebih dari satu jawaban } \\
\text { 3. Menyelesaikan pekerjaan lebih cepat dari teman lainnya } \\
\text { 4. Melakukan lebih banyak pekerjaan dari teman lainnya } \\
\text { 5. Melihat kesalahan atau kelemahan dari suatu situasi atau } \\
\text { obyek secara lebih cepat dari mahasiswa lainnya }\end{array}$ \\
\hline 2 & $\begin{array}{l}\text { Berpikir } \\
\text { luwes }\end{array}$ & $\begin{array}{l}\text { 1. Memberikan berbagai macam penafsiran terhadap suatu } \\
\text { obyek atau masalah yang sedang dihadapi } \\
\text { Menerapkan konsep atau azas dengan cara unik dan } \\
\text { berbeda } \\
\text { 3elalu memiliki posisi yang berbeda atau bertentangan } \\
\text { dengan pendapat mayoritas kelompok ketika } \\
\text { memberikan pertimbangaan saat diskusi berlangsung. }\end{array}$ \\
\hline
\end{tabular}




\begin{tabular}{|c|c|c|}
\hline & & $\begin{array}{l}\text { 4. Jika diberi suatu masalah, biasanya memikirkan berbagai } \\
\text { alternatif penyelesaian masalah dengan cara yang } \\
\text { berbeda pada umumnya }\end{array}$ \\
\hline 3 & $\begin{array}{l}\text { Berpikir } \\
\text { orisinil }\end{array}$ & $\begin{array}{l}\text { 1. Memikirkan hal yang jarang dipikirkan oleh orang lain } \\
\text { pada umumnya. } \\
\text { 2. Cara berpikirnya mileneal selalu memikirkan cara-cara } \\
\text { baru dan meninggalkan cara-cara lama. } \\
\text { 3. Memberikan gagasan yang baru dalam menyelesaikan } \\
\text { masalah }\end{array}$ \\
\hline 4 & $\begin{array}{l}\text { Berpikir } \\
\text { elaboratif }\end{array}$ & $\begin{array}{l}\text { 1. Memperkaya gagasan yang disampaikan orang lain } \\
\text { 2. Penyelesaian masalah senantiasa dilakukan melalui } \\
\text { tahapan-tahapan yang rinci. } \\
\text { 3. Cenderung memberikan jawaban yang luas, terperinci } \\
\text { dan memuaskan } \\
\text { 4. Mampu mengkonstruksi keterkaitan satu konsep dengan } \\
\text { konsep lainnya }\end{array}$ \\
\hline 5 & $\begin{array}{l}\text { Berpikir } \\
\text { evaluatif }\end{array}$ & $\begin{array}{l}\text { 1. Memberi pertimbangan atas berbagai sudut pandang, } \\
\text { 2. Menganalisis masalah secara kritis dengan selalu } \\
\text { menanyakan sesuatu dengan kata tanya "mengapa" } \\
\text { 3. Memiliki alasan yang rasional dan dapat } \\
\text { dipertanggungjawabkan }\end{array}$ \\
\hline
\end{tabular}

\section{HASIL DAN PEMBAHASAN}

Data hasil penelitian berupa perkembangan kemampuan berpikir kreatif mahasiswa peserta kuliah untuk matakuliah Strategi Pembelajaran Fisika dalam bentuk perkuliahan LC yang datanya direkam menggunakan instrumen kemampuan berpikir kreatif dengan indikator yang mencakup lima aspek sebagaimana tertera pada Tabel 2 berikut.

Tabel 2. Prosentase Peningkatan Kemampuan Berpikir Kreatif

\begin{tabular}{|l|c|c|c|c|c|}
\hline \multicolumn{7}{|c|}{ Aspek Kemampuan Berpikir Kreatif (\%) } \\
\hline & Lancar & Luwes & Orisinil & Elaborasi & Evaluatif \\
\hline Sebelum & 62,07 & 58,62 & 72,41 & 68,97 & 72,41 \\
\hline Sesudah & 79,31 & 82,76 & 82,76 & 89,66 & 86,21 \\
\hline Peningkatan & 17,24 & 24,14 & 10,34 & 20,69 & 13,79 \\
\hline \multicolumn{5}{|l|}{ Rerata peningkatan (\%) } & \multicolumn{5}{|c|}{17,24} \\
\hline
\end{tabular}

Berdasarkan hasil analisis data sebagaimana Tabel 2 di atas nampak bahwa pembelajaran dalam bentuk $L C$ secara umum berdampak baik pada tumbuhnya kemampuan berpikir kreatif mahasiswa. Berkembangnya kemampuan bepikir kritis nampak dominan pada aspek kemampuan berpikir elaborasi hingga mencapai 89,66\% dengan kategori sangat baik, sedangkan prosentase ketercapaian kemampuan berpikir kritis pada aspek berpikir lancar masih terkategori cukup dengan prosentase pencapaian sebesar 79,31\%. Hal ini menunjukkan bahwa pembelajaran dengan prinsip belajar mandiri dan saling belajar antar anggota komunitas dapat memperkaya gagasan ataupun ide-ide inovatif mahasiswa. 
Dalam proses pembelajaran, ada 6 tingkatan ranah kompetensi kognitif (pengetahuan) yang harus dicapai mahasiswa, mengingat (remembering), memahami (understading), mengaplikasikan (applying), menganalisis (analyzing), megevaluasi (evaluating) dan mengkreasi atau creating (Anderson, 2011). Dalam pembelajaran Laerning Community ini, ranah kompetensi mengingat (remembering) dikembangkan dan dilakukan di luar jam tatap muka serta dilakukan jauh lebih awal sebelum mahasiswa mengikut perkuliahan, melalui pemberian tugas terkait topik yang akan dibahas secara on-line. Saat kuliah berlangsung, kesempatan bagi mahasiswa untuk saling bertukar informasi sesama komunitas belajarnya. Kemampuan berpikir kritis mulai muncul ketika setiap individu dalam komunitas memiliki sumber belajar dan pengetahuan yang semakin beragam. Semakin banyak muncul perbedaan pendapat ataupun konsep dalam sebuah komunitas belajar akan semakin baik. Situasi belajar bermakna ini berdampak pada peningkatan kemampuan berpikir kreatif yang signifikan pada aspek berpikir luwes hingga mencapai 24,14 persen. Keragaman pengetahuan awal yang mereka peroleh dari media on line akan melatih cara berpikir mereka untuk memberikan berbagai penafsiran yang beragam. Keragaman penafsiran dalam suatu konsep akan bermuara pada munculnya berbagai alternatif penyelesaian masalah yang unik dari setiap individu.

Hasil analisis di atas juga menunjukkan bahwa kolaborasi pembelajaran yang terjadi antara sesama mahasiswa dalam satu komunitas memberikan peluang untuk terjadinya saling memberi antara mahasiswa satu dengan yang lainnya. Komunikasi positif antara peserta kelompok komunitas menjadi semakin lebih interaktif terjadi ketika perbedaan konsep, pengetahuan ataupun pendapat diantara mereka mulai bermunculan. Dalam diskusi, tidak ada peserta menjadi lebih pintar satu sama lainnya, karena masing-masing komunitas telah memiliki bekal pengetahuan awal (entry level) yang sama yang diperolehnya secara on line. Perbedaan akan muncul ketika anggota komuitas memiliki sumber yang lebih dibandingkan anggota lainnya. Semakin ada perbedaan ide maupun gagasan dalam suatu komunitas belajar, semakin menujukkan adanya keragaman sudut pandang cara berpikirnya. Keragaman ide ini akan mengkonstruksi adanya pemikiran-pemikiran unik atau hal-hal yang tidak pernah dipikirkan oleh orang lain pada umumnya serta akan selalu memikirkan cara-cara baru dalam menyelesaikan suatu masalah. Dampak ini terasa siginifikan dalam meningkatkan kemampuan berpikir orosinil hingga mencapai 10,34\%.

Prinsip saling belajar dalam pembelajaran LC ini juga memberi kesempatan yang luas bagi setiap mahasiswa untuk membangun keterkaitan satu konsep dengan konsep lainnya yang bersumber dari sumber belajar yang beragam. Setiap individu dalam kelompok komunitas belajar ini adalah juga merupakan sumber belajar bagi individu lain. Suasana saling belajar ini mampu membangun ketrampilan berpikir 
elaboratif mahasiswa. Hasil analisis menunjukkan bahwa kemampuan berpikir kreatif pada aspek elaboratif ini mengalami peningkatan cukup signifikan dan terbesar dibandingkan aspek lainnya hingga mencapai 20,69\%.

Komunitas yang setara (sebaya) memberi keyakinan kepada setiap mahasiswa untuk dapat menyampaikan pendapatnya secara terbuka tanpa khawatir akan kesalahan yang mungkin terjadi. Disinilah akan muncul sikap evaluatif serta menghargai pendapat orang lain. Dalam sebuah komunitas dengan beragam ide dan pengetahuan awalnya memberi kesempatan yang luas bagi setiap anggota komunitas untuk menampilkan ideide evaluatif yang merupakan sumber munculnya gagasan-gagasan baru yang unik sehingga setiap individu mahasiswa akan mampu memberi pertimbangan atas dasar sudut pandang sendiri. Kemampuan berpikir secara evaluatif dalam penelitian meningkat hingga mencapai $13,79 \%$. Selain itu, perbedaan sumber belajar dan pengetahuan awal (entry level) dalam sebuah komunitas memberi ruang dan waktu bagi setiap individu mahasiswa untuk berpikir secara evaluatif yang beragam.

Besarnya peningkatan kemampuan berpikir kritis untuk kelima aspek secara representatif digambarkan dalam Grafik 1 berikut.

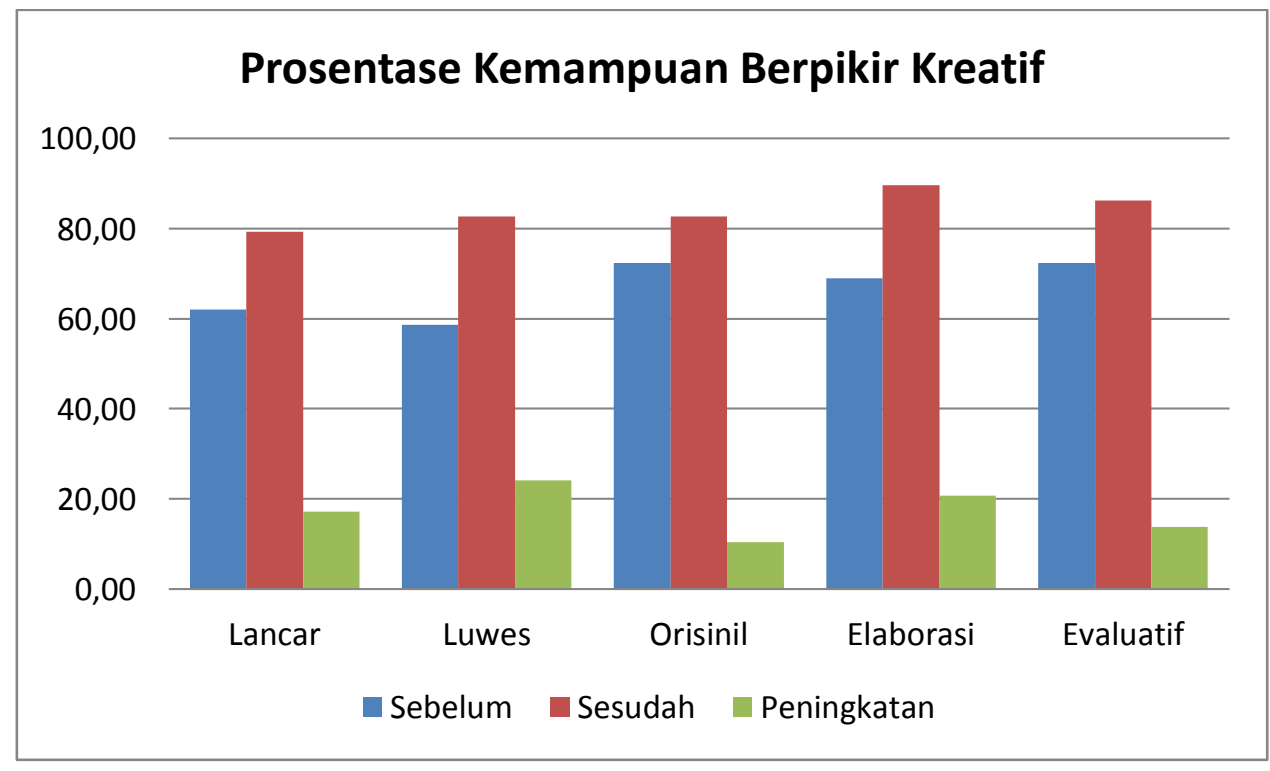

Gambar 1. Grafik Prosentase Ketercapaian Kemampuan Berpikir Kreatif

Berdasarkan hasil analisis sebagaimana diuraikan di atas, secara umum dapat dikatakan bahwa pembelajaran Learning Community pada perkuliahan matakuliah Strategi Pembelajaran Fisika berdampak positif pada terbentuknya kemampuan mahasiswa dalam berpikir secara kreatif dengan ketercapaian antara 79,31 sampai dengan 89,66 persen. Hal ini menunjukkan bahwa sebanyak 84,14 persen mahasiswa peserta kuliah Strategi Pembelajaran Fisika telah memiliki kemampuan dasar yang cukup baik untuk berpikir secara kreatif sebagai dampak perkuliahan dalam bentuk Learning Community. 
Konsep sharing, saling menghargai dalam menyampaikan pendapat dan kolaboratif dalam pembelajaran LC berdampak positif dalam membangun kemampuan mahasiswa dalam berkomunikasi. Setiap mahasiswa sebagai anggota komunitas belajar akan belajar membangun komunitas yang tidak saling menyalahkan namun membangun sebuah komuitas yang menganut prinsip bahwa apapun pendapat orang lain setidaknya akan bermakna bagi setiap anggota komunitas. Keberhasilan dalam menata pembelajaran dalam bentuk kelompok yang dilandasi oleh saling belajar, teman sebaya sebagai sumber belajar dan dinamika kelompok sebagai sumber keragaman pengalaman belajar masing-masing individu mahasiswa berdampak terhadap meningkatnya kemampuan berpikir kreatif mahasiswa peserta kuliah sebesar 17,24 \%.

Berdasarkan hasil analisis di atas, maka dapat dikatakan bahwa Learning Community atau komunitas belajar dalam tatanan perkuliahan di Perguruan Tinggi merupakan suatu konsep terciptanya masyarakat belajar di lingkungan kampus. LC memberikan ruang dan waktu kepada seluruh pelaku pembelajaran untuk melakukan proses belajar membelajarkan, baik antara dosen dengan dosen, dosen dengan mahasiswa, mahasiswa dengan mahasiswa, dan bahkan antara masyarakat kampus dengan masyarakat di luar kampus. Tujuannya adalah agar pencampaian komptensi pembelajaran dapat lebih ditingkatkan. Pada mulanya, konsep LC ini dimunculkan sebagai jawaban atas berbagai masalah pendidikan di Jepang serta pendobrak pandangan yang waktu itu berlangsung yakni bahwa tugas guru adalah mengajar dan tugas siswa adalah belajar, yang diganti dengan tugas guru adalah belajar agar dapat mengajar lebih baik. Konsep pembelajaran LC ini pun akhirnya berkembang luas dan mulai diimplementasikan hingga tingkat Perguruan Tinggi.

Pembelajaran berbasis LC merupakan salah satu bentuk pembelajaran yang lebih mengutamakan konsep saling belajar antara mahasiswa satu dengan yang lainnya dalam sebuah komunitas belajar. Konsep ini mengandung makna bahwa dalam proses pembelajaran, setiap peserta kuliah memiliki hak dan kesempatan yang sama untuk mengembangkan kompetensinya dan saling memberi dan membantu satu sama lainnya. Dalam perkuliahan, bentuk pembelajaran $L C$ ini dapat dikombinasikan dengan bentuk pembelajaran yang berpusat pada mahasiswa yang lebih mengutamakan keaktifan mahasiswa dalam proses pembelajaran. Pembelajaran akftif di Perguruan Tinggi yang sering disebut dengan Active Learning in Higher Education (ALIHE) memberikan kesempatan kepada mahasiswa untuk tidak saja mengembangkan kemampuan kognitifnya, namun akan mengasah sikap dan soft skill mahasiswa, karena salah satu karakteristik proses pembelajaran ALIHE adalah berpusat pada mahasiswa dan kolaboratif (Permenristekdikti No. 44, 2015), yang tidak jauh berbeda dengan konsep pembelajaran Learning Community. 
Dengan demikian berdasarkan analisis dan uraian di atas, maka dapat dikatakan bahwa LC merupakan salah satu bentuk pembelajaran yang dapat meningkatkan kualitas pembelajaran yang berorientasi pada SCL yang secara spesifik dalam penelitian ini telah menumbuhkan kemampuan berpikir kreatif mahasiswa peserta kuliah Strategi Pembelajaran Fisika.

\section{SIMPULAN}

Berdasarkan hasil analisis sebagaimana uraian di atas, maka dapat disimpulkan sebagai berikut.

1. Learning Community merupakan salah satu bentuk pembelajaran yang berpusat pada mahasiswa (Student Centered Learning) yang menitik beratkan pada konsep belajar dalam kelompok, saling bekerjasama, sharing dan menciptakan suasana belajar untuk saling belajar dalam wadah komunitas belajar sehingga tercipta proses pembelajaran yang lebih bermakna dan berkualitas.

2. Pembelajaran dalam bentuk LC pada perkuliahan Strategi Pembelajaran Fisika efektif untuk membentuk kemampuan mahasiswa dalam berpikir kreatif yang mencakup lima aspek yaitu kemampuan dalam berpikir lancar, luwes, orisinil, elaborasi dan evaluatif dengan ketercapaian rerata sebesar 84,14 persen.

3. Pembelajaran dalam bentuk LC pada perkuliahan Strategi Pembelajaran Fisika efektif dalam meningkatkan kemampuan berpikir kreatif mahasiswa perserta kuliah Stategi Pembelajaran Fisika secara umum sebesar 17,24 persen.

\section{SARAN DAN UCAPAN TERIMA KASIH}

Agar bentuk implementasi $L C$ dalam perkuliahan lebih bervariasi, maka perlu kiranya dilakukan penelitian lebih lanjut dengan mengkolaborasikan LC dengan pendekatan SCL lainnya, misalnya dengan Selft Directed Learning (SDL).

Dalam kesempatan ini, terima kasih penulis sampaikan kepada Dirjen Belmawa atas dukungannya dalam penelitian ini melalui program Penugasan Dosen ke Sekolah (PDS) skema B yang pada Tahun 2019 ini implementasinya di Perguruan Tinggi yakni di Prodi. Fisika FKIP Undana pada perkuliahan matakuliah Strategi Pembelajaran Fisika.

\section{REFERENSI}

Anderson, L. W., Krathwohl, D. R., Airasian, P. W., Cruikshank, K. A., Mayer, R. E., \& Pintrinch, P. R. 2001. A Taxonomy for Learning, Teaching, and Assessing: A Revision of Bloom's Taxonomy of Educational Objectives. New York: Longman.

Anisa Y., Dharmono, Akhmad Naparin, Muhamad Zaini. 2018. Kemampuan Berpikir Kreatif Mahasiswa Pendidikan Biologi dalam Penyelesaian Masalah Ekologi Tumbuhan, Jurnal Bioedukasi, Vol. 11 No.1, Pebuari 2018. 
Elfindri, dkk. 2012. Pendidikan Karakter, Kerangka, Metode dan Aplikasi untuk Pendidikan dan Profesional. Jakarta:Baduose Media.

Festiyed. 2016. Perubahan Paradigma Pendidikan: Peningkatan Layanan Profesional Melalui Pembelajaran Autentik Dan Asesmen Autentik, Disampaikan Pada Seminar Nasional dan Forum Pimpinan Pascasarjana LPTK Negeri se Indonesia. Dengan Tema: Mewujudkan sinergisitas LPTK dalam mengembangkan kemitraan sumber daya Pascasarjana LPTK di era MEA, 7-9 oktober 2016 di Training Centre, Damhill Hotel, Universitas Negeri Gorontalo.

Firdausi, Y.N., M.Asikin, Wuryanto. 2018. Analisis Kemampuan Berpikir Kreatif Siswa Ditinjau dari Gaya Belajar pada Pembelajaran Model Eliciting Activities (MEA), Prisma, Prosiding Seminar Nasional Matematika, FMIPA Universitas Negeri Semarang, https://journa.unnes.ac.id/sju/index.php/prisma/.

Hastjarjo,T. Dicky. 2019. Rancangan Eksperimen-Kuasi. Buletin Psikologi 2019, Vol. 27, No. 2, 187 - 203, DOI: 10.22146/buletinpsikologi.38619, https://jurnal.ugm. ac.id /buletinpsikologi

http://repository.fkip.unja.ac.id/file?i=A ZJMKcQqHiOcNXSISiDKWf3GUhin5 2h agAgYXMXek, kemampuan berpikir kreatif, diakses 8 Agustus 2019.

Istamar Syamsuri dan Ibrohim. 2008. Lesson Study (Studi Pembelajaran) Model Pembinaan Pendidik Secara Kolaboratif dan Berkelanjutan; dipetik dari Program SISTTEMS-JICA di Kabupaten Pasuruan Jawa Timur (2006-2008). Malang: FMIPA UM, 2008.

Jona. A. 2010. Berpikir kreatif dan Kritis. http://jonaagatos.weebly.com/bab-vi-berpikirkreatif-dan-kritis.html. Diakses tanggal 25 Nopember 2019.

Kurniawan, Yusuf. 2018. Peran Teman Sebaya dalam Pembentukan Karakter Siswa Madrasah Tsanawiyah. Socia: Jurnal Ilmu-ilmu Sosial, Vol. 15 No.2 Tahun 2018.

Liliawati, W. 2011. Pembekalan Keterampilan Berpikir Kreatif Siswa Sma Melalui Pembelajaran Fisika Berbasis Masalah. Jurnal Pengajaran MIPA, Volume 16, Nomor 2, Oktober 2011.

Lillie G. Jessie. 2007. The Elemen of a Professional Learning Community. Journal Leadership ASHE-EROC Higher Education Report. Volume 26, No. 4:53-64.

Louise Stoll, Ray Bolam, Agnes McMahon, M Wallace, and Sally Thomas. 2006. Professional Learning Communities: A Review of The Literature. Jornal of Educational Change, 2006 ( 221-258).

Mahmudi, Ali. 2010. Pengembangan Rencana Pembelajaran Berbasis Kontekstual. Diakses tanggal 17 April 2020 dari http://staff.uny.ac.id/sites/default/files/tmp/ Makalah\%20Pengembangan\%20RPP\%20Berbasis\%20 Kontekstual_0.pdf.

Mustadi, A.. 2017. Reformasi Sekolah melalui Learning Community based Lesson Study (LCLS) di Sekolah Dasar, Inopendas Jurnal Ilmiah Kependidikan, Vol 1. No.1 Pebruari 2018.

Permenristekdikti No. 44 Tahun 2015 tentang Standar Nasional Pendidikan Tinggi.

Purwaningrum, J.P. 2016. Mengembangkan Kemampuan Berpikir Kreatif Matematis Melalui Discovery Learning Berbasis Scientific Approach. Jurnal Refleksi Edukatika, Vol. 6 No. 2, Juni 2017.

Putri, S.W., Saddam Hussen, Robiatul Adawiyah. 2017. Kemampuan Berpikir Kreatif Dalam Menyelesaikan Masalah Kesebangunan di SMPN 11 Jember. Junal Edukasi Vol. 4 No. 3 Tahun 2017.

Saefudin, Abdul Aziz. 2012. Pengembangan Kemampuan Berpikir Kreatif Siswa dalam Pembelajaran Matematika dengan Pendekatan Pendidikan Matematika Realistik Indonesia (PMRI). Yogyakarta: Jurnal AL Badiyah, Vol 4 No1.

Sani. 2014. Pembelajaran Saintifik untuk Implementasi Kurikulum 2013, Jakarta: Bumi Aksara.

Sinaga, Hotmaidah. 2017. Meningkatkan Prestasi Belajar IPS dengan Pendekatan Pembelajaran Learning Community di Kelas VIII.1 SMP Negeri 5 Tebing Tinggi. School Education Journal, Vol. 7 No. 4 Tahun 2017.

Soeyono, Y. (2014). Pengembangan Bahan Ajar Matematika dengan Pendekatan OpenEnded untuk Meningkatkan Kemampuan Berpikir Kritis dan Kreatif Siswa SMA. 
Pythagoras: Jurnal Pendidikan Matematika, 9(2)., 2014.

Sudirtha. 2017. Membangun Learning Community dan Peningkatkan Kompetensi Melalui Lesson Study. Jurnal Pendidikan Indonesia, P-ISSN: 2303-288X E-ISSN: 25417207 Vol. 6, No.1, April 2017.

Sugiyono. 2013. Metode Penelitian Pendidikan. Bandung: Alfabet.

Suripah, S., Aulia Sthephani. 2017. Kemampuan Berpikir Kreatif Matematis Mahasiswa dalam Menyelesaikan Akar Pangkat Persamaan Kompleks Berdasarkan Tingkat Kemampuan Akademik. Pythagoras: Jurnal Pendidikan Matematika, 12 (2), 2017.

Surya. H. 2013. Cara Belajar Orang Jenius. Jakarta: Elex Media Komputindo.

Susanto. 2013. Teori Belajar dan Pembelajaran di Sekolah Dasar. Jakarta: PT. Fajar Interpratama Mandiri.

Yuli Munazah, Sugianto, Sunyoto Eko Nugroho. 2015. Model Learning Community Berbasis Inkuiri Terbimbing untuk Meningkatkan Hasil Belajar Siswa dalam Pelajaran IPA Fisika SMP. UNNES Physics Education Journal, Vol.4 No.3, Oktober 2015. 